\title{
PENGALAMAN SEKSUALITAS PEREMPUAN MENOPAUSE
}

\author{
Puspita Palupi $^{1,2^{*}}$, Yati Afiyanti ${ }^{3}$, Imami Nur Rachmawati ${ }^{3}$ \\ 1. PSIK FKIK, Universitas Islam Negeri Syarif Hidayatullah, Jakarta 15412, Indonesia \\ 2. Program Studi Magister, Fakultas Ilmu Keperawatan, Universitas Indonesia, Depok 16424, Indonesia \\ 3. Fakultas Ilmu Keperawatan, Universitas Indonesia, Depok 16424, Indonesia \\ *E-mail: palupipuspita@yahoo.com
}

\begin{abstract}
Abstrak
Penelitian ini bertujuan untuk memperoleh gambaran makna dan arti pengalaman seksualitas perempuan menopause. Sebanyak delapan perempuan yang mengalami menopause paling lama tiga tahun berpartisipasi dalam penelitian fenomenologi deskriptif ini melalui wawancara mendalam. Partisipan diperoleh melalui purposive sampling. Data dianalisis dengan metode Collaizi. Hasil penelitian menemukan enam tema: 1) Makna hubungan seksual; 2) Perubahan siklus respon seksual pada masa menopause; 3) Dimensi psikologis dalam seksualitas; 4) Dimensi sosiokultural dalam seksualitas; 5) Kebahagiaan seksualitas pada masa menopause; dan 6) Kebutuhan informasi tentang pelayanan kesehatan seksual. Hasil ini memberikan gambaran pentingnya perawat maternitas memahami dimensi seksualitas perempuan menopause untuk meningkatkan kualitas hidup mereka. Diperlukan penelitian selanjutnya terutama yang mengeksplorasi secara mendalam dimensi seksualitas khususnya psikologis dan sosiokultural pada perempuan menopause.
\end{abstract}

Kata kunci: dimensi seksualita, pengalaman seksualitas, perempuan menopause

\begin{abstract}
Sexualilty Experiences of Menopausal Women. The objective of this research was to obtain the sense and meaning of sexual experiences of menopausal women. The researcher applied a phenomenological descriptive design. Data were collected using in-depth interview method. The participants were menopausal women up to three years of menopausal time obtained through a purposive sampling. Data were analyzed using a Collaizi's technique. Six themes were identified: 1) meaning of sexual relationship; 2) changes of sexual cycle responses in menopause; 3) psychological dimension of sexuality; 4) socio-cultural dimension of sexuality; 5) sexuality happiness in menopause; 6) and informational needs of sexual health service. The results suggest that health workers especially maternity nurses should understand sexuality dimension of menopausal women in order to improve their quality of life. A further research on exploration of sexuality dimension especially psychological and socio-cultural dimension on menopausal women is required.
\end{abstract}

Keywords: dimension of sexuality, menopausal women, sexuality experience

\section{Pendahuluan}

Indikator keberhasilan di bidang kesehatan salah satunya adalah usia harapan hidup yang meningkat. BPS (2012) melaporkan bahwa angka harapan hidup penduduk Indonesia naik dari 67,8 tahun pada periode 2000-2005 menjadi 73,7 tahun pada periode 2020-2025 dengan perkiraan jumlah penduduk Indonesia akan mencapai 273,65 juta jiwa pada tahun
2025. Seiring dengan meningkatnya angka harapan hidup semakin bertambah pula jumlah perempuan menopause yang merupakan bagian dari cakupan kesehatan perempuan.

Menopause merupakan peristiwa berakhirnya siklus menstruasi alami yang teratur karena produksi estrogen yang berkurang dan tidak terjadi menstruasi kembali (Mayo, 2000). Seiring dengan adanya perubahan pada masa 
menopause menyebabkan berbagai masalah termasuk berkaitan dengan pemenuhan kebutuhan seksual mereka dan pasangannya.

Seksualitas merupakan bagian terpenting dalam kesehatan perempuan dan juga kualitas hidup perempuan (Barsky, Friedman, \& Rosen, 2006). Banyak faktor yang dapat mempengaruhi fungsi seksual perempuan antara lain biologis, psikologis, dan sosial budaya. Aspek seksualitas pada perempuan menopause merupakan salah satu bagian dari kebutuhan dasar manusia yang memiliki porsi yang sama dengan pemenuhan kebutuhan dasar lainnya. Seiring dengan adanya berbagai perubahan pada masa menopause menyebabkan berbagai masalah salah satunya terkait dengan pemenuhan kebutuhan seksualnya.

Penelitian Schultz-Zehden dan Rosemeier (1998) di Berlin menyebut 35\% perempuan menopause mengalami masalah ketidaknyamanan ketika berhubungan seksual karena berkurangnya lubrikasi vagina. Dennerstein dan Lehert (2004) melaporkan $31 \%$ kejadian disfungsi seksual pada perempuan menopause menunjukkan adanya penurunan hasrat seksual. Jinzhu dan Eden (2007) juga melaporkan di Cina terdapat perubahan dalam seksualitas yang berbeda pada masa premenopause, peri-menopause, dan paska menopause karena vagina yang kering. Perubahan pada perempuan menopause secara psikososial seperti kecemasan, iritabilitas, dan depresi ternyata berdampak pada aspek seksualitas (Hartmann, Phillippsohn, Heiser \& RufferHesse, 2004).

Penelitian di Spanyol mengenai pengalaman seksualitas selama menopause menghasilkan empat kategori utama yaitu makna perempuan pada masa menopause, perubahan secara biologis yang relatif, perjalanan kehidupan seksual dan pentingnya faktor sosial dan keluarga yang dapat mempengaruhi pengalaman seksualitas (Goberna, et al., 2009). Goncalves dan Merighi (2009) melaporkan bahwa pengalaman seksualitas merupakan sesuatu yang kompleks karena mencakup berbagai aspek dalam kehidupan yang tidak terbatas pada aspek biologis saja, sehingga terkadang isu seksualitas kurang bermakna penting di kalangan petugas kesehatan karena kesulitan dan keterbatasan memahami masalah ini.

Penelitian mengenai menopause telah banyak dilakukan, namun di kalangan perempuan Indonesia permasalahan seputar seksualitas saat ini masih belum banyak terungkap. Seksualitas, bagaimanapun sangat berkaitan dengan latar belakang budaya yang menganggap tabu untuk dibicarakan dan belum tereksplorasi secara mendalam terutama ungkapan langsung dari para perempuan menopause. Studi ini bertujuan mengeksplorasi makna dan arti pengalaman seksual perempuan menopause di Indonesia lebih mendalam dengan tidak terbatas pada dimensi fisiologis saja tetapi juga pada dimensi psikologis dan sosial budaya dengan menggunakan pendekatan kualitatif. Ungkapan langsung terhadap isu ini dari partisipan dapat memberikan gambaran yang jelas tentang apa saja pengalaman seksualitas perempuan menopause untuk mengarahkan pelayanan kesehatan perempuan sesuai dengan kebutuhan.

\section{Metode}

Penelitian dengan pendekatan fenomenologi deskriptif ini menggunakan wawancara mendalam yang direkam dan catatan lapangan untuk pengumpulan data pada perempuan yang mengalami menopause tidak lebih dari tiga tahun di wilayah Jakarta Timur. Persetujuan etik diperoleh dari Komite Etik Penelitian Fakultas Ilmu Keperawatan Universitas Indonesia. Analisis transkrip wawancara menggunakan metode Colaizzi.

\section{Hasil}

Delapan perempuan berpartisipasi, mereka sudah mengalami menopause selama satu sampai tiga tahun, berusia 45 sampai 55 tahun, berpendidikan SD sampai DIII. Hampir semua partisipan beragama Islam hanya satu partisipan yang beragama Katholik. Mayoritas suku Jawa dan hanya satu partisipan suku 
Sunda. Sebagian besar sebagai ibu rumah tangga namun ada juga sebagai PNS.

Hasil analisis dengan Colaizzi memperoleh tema: 1) Makna hubungan seksual; 2) Perubahan siklus respon seksual pada masa menopause; 3) Dimensi psikologis dalam seksualitas; 4) Dimensi sosiokultural dalam seksualitas; 5) Kebahagiaan seksualitas pada masa menopause; dan 6) Kebutuhan informasi tentang pelayanan kesehatan seksual. Berikut uraian secara terinci tema dan contoh kutipan ungkapan partisipan.

Makna Hubungan Seksual. Sebagian besar partisipan menyatakan makna hubungan seksual merupakan bentuk cinta dan kasih sayang terhadap pasangannya, hubungan seksual membuat lebih dekat dan intim dengan suami, sebagai kebutuhan yang harus terpenuhi dan bentuk kewajiban seorang istri pada suami.

"menurut saya arti hubungan suami istri sebagai bentuk rasa cinta..." (P3)

“....menurut saya berhubungan badan dengan bapak membuat saya jadi tambah dekat dan sayang sama dia...” (P8)

“...berhubungan badan merupakan suatu kebutuhan baik bagi suami atau istri”(P4).

"kalau menurut saya hubungan suami istri hanya sekedar untuk menjalani kewajiban sebagai istri..."(P4).

\section{Perubahan Siklus Respon Seksual pada Masa}

Menopause. Secara fisiologis pada perempuan menopause terjadi penurunan fungsi hormonal yang menyebabkan beberapa perubahan. Semua partisipan merasakan terjadi perubahan pada respon seksual (excitement, plateau, orgasmic, dan resolution). Berikut ini merupakan ungkapan salah satu partisipan yang mengalami fase rangsangan (excitement dan plateau) yang memanjang.

“...beda kayak waktu dulu (sebelum menopause) baru dicumbu sebentar sudah agak basah kalau sekarang masih saja tetap kering meski udah diapain aja..." (P1).

Ketidaknyamanan ketika berhubungan seksual juga menyebabkan ketidakpuasan seksual. Hal ini merupakan salah satu perubahan siklus respon pada fase orgasmic.

“...saya jadi merasa kurang puas kalau habis berhubungan karena yang saya lakukan hanya sekedar memenuhi kemauan bapaknya aja..." (Pl).

Semua partisipan tidak mengalami perubahan pada fase terakhir siklus respon seksual yaitu resolusi.

“...kalau saya saat selesai campur masih sama seperti dulu waktu sebelum menopause..."(P1).

Semua partisipan dalam studi ini mengekspresikan adanya keluhan nyeri saat melakukan hubungan seksual karena lubrikasi vagina mereka menjadi berkurang.

"kemaluan saya jadi kering banget, padahal waktu sebelum menopause gak kaya gini...”(P2).

Penurunan frekuensi, durasi, dan gairah berhubungan seksual akibat ketidaknyamanan fisik yang terjadi saat menopause.

“...waktu dulu sebelum menopause bisa lama banget kalau campur hampir 1 jam sampe selesai, tapi sekarang kadang gak sampe 1/2 jam..." (P4).

"saya merasakan setelah menopause ini benar-benar keinginan atau gairah saya buat atau campur sama suami jadi kurang..."(P1).

“......yang jelas jadi gak terlalu sering sekarang jadi seminggu sekali... waktu sebelum menopause seminggu bisa 2-3 kali ..." (P3).

Dimensi Psikologis dalam Seksualitas. Semua partisipan mengungkapkan gambaran diri yang berkaitan dengan aspek seksualitas berbedabeda. Ada yang menganggap dirinya sebagai 
perempuan yang sempurna atau sebaliknya merasa sudah mulai tua, keriput, rambut banyak beruban, tidak cantik lagi, dan kurang bisa memuaskan suami di tempat tidur

"saya memandang bahwa diri saya seorang wanita yang sempurna karna telah menjalankan tugas-tugas perempuan sampai mengalami menopause.." (P3).

“...udah gak sempurna lagi sejak menopause karena muka saya udah terlihat tua dan keriput, gak cakep lagi, kulit sudah mulai kendur, rambut sudah banyak yang beruban, dan juga sudah kurang bisa memuaskan suami di ranjang tidak seperti sebelum menopause" (P2).

Ada partisipan yang merasa tetap percaya diri meskipun memiliki keterbatasan saat berhubungan seksual apalagi suaminya sama sekali tidak mempermasalahkan berbagai perubahan yang terjadi.

"saya tetap percaya diri meskipun banyak gak nyaman pada diri saya saat berhubungan badan dan suami pun tidak mempermasalahkan ini malah menurutnya pelayanan yang saya berikan buat suami dirasakan puas..."(P1).

Partisipan yang merasa kurang percaya diri merasa khawatir bahwa perubahan yang dialaminya tidak bisa memberikan kepuasan pada suami.

"saya banyak mengalami perubahan saat menopause yang kadang membuat saya kurang percaya diri sehingga saya menjadi sangat khawatir tidak bisa memuaskan suami ..."(P2).

Semua partisipan mengungkapkan sejak belum menikah atau setelah menikah belum pernah memiliki riwayat traumatis dalam membina hubungan dengan pasangan ataupun masalah kekerasan seksual lainnya.

"saya belum pernah pacaran dengan laki-laki lain selain bapak, jadi setelah ketemu bapak, saya segera nikah. Jadi gak punya pengalaman apa-apa dalam berhubungan sama orang lain... hubungan saya dengan bapak sejak pertama menikah baik-baik aja... saya pun belum pernah disakiti sama bapak untuk urusan di ranjang dari sejak nikah dulu.." (Pl).

Dimensi Sosiokultural dalam Seksualitas. Sebagian partisipan mengungkapkan penilaian suami terhadap dirinya sebagai perempuan yang hebat dan sempurna.

"suami menilai saya adalah perempuan hebat bisa memberikan keturunan yang baik, sudah sempurna menjadi seorang ibu yang baik terhadap anak maupun suami..."(P2).

Partisipan mengungkapkan dirinya masih dianggap selalu bersemangat meskipun sudah menopause. Ada yang juga merasa bahwa dirinya dinilai awet muda.

"teman-teman menganggap saya masih selalu semangat meskipun udah menopause” (P4).

"orang sekitar sini menganggap bahwa meskipun saya sudah menopause saya tetap belum kelihatan tua..."(P1)

Sisi negatif perempuan menopause juga ditemukan. Masyarakat mengganggap bahwa perempuan menopause sudah "baki atau gabuk". Yang lain mengatakankan perempuan menopause dianggap sebagai perempuan yang tidak sempurna termasuk di dalamnya kurang memberikan kepuasan bagi suami.

“..kalau orang sudah menopause menurut budaya Jawa dianggap sudah gabuk atau baki...maksudnya perempuan menopause dianggap sudah tua dan gak bisa hamil atau punya anak lagi..."(P1).

"orang menopause dianggap sebagai perempuan yang gak sempurna, udah gak bisa apa-apa lagi...menurut budaya setempat bahwa perempuan menopause udah gak bisa lagi memuaskan suami di tempat tidur..." (P7). 
Peran seksual istri dalam aspek seksualitas menurut pandangan budaya. Sebagian besar partisipan menyatakan bahwa istri dianggap pamali atau pantang berinisiatif dalam hubungan seksual.

“...dari sejak dulu sebelum menopause suami saya yang selalu minta duluan karna kalau kata orang Jawa pamali perempuan bilang dulu ke suami kalau pengin campur"(P1).

Ada partisipan yang mengungkapkan bahwa setiap perempuan harus taat dan tunduk kepada suami.

“...menurut budaya Jawa, istri sebagai orang yang harus berada di bawah suami dan tunduk dengan seтua kata-kata suami dan gak boleh melawan"(P1).

\section{Kebahagiaan Seksualitas pada Masa Meno-} pause. Salah satu kesenangan setelah menopause adalah tidak perlunya biaya untuk kontrasepsi. Periode menopause juga membuat suami istri bebas melakukan hubungan seksual tanpa ada kekhawatiran atau ketakutan terjadi kehamilan.

“....sekarang saya udah gak perlu keluar uang untuk biaya KB, jadi uang bisa dipakai buat keperluan yang lainnya" (P3).

"saya udah bebas berhubungan badan sama bapaknya, kapan aja bisa dilakuin tanpa ada rasa takut hamil"(P4).

\section{Kebutuhan Informasi tentang Pelayanan} Kesehatan Seksual. Semua partisipan mengungkapkan kebutuhan kesehatan seksual yang saat ini diperlukan adalah cara mengurangi ketidaknyamanan saat berhubungan seksual.

“...bagaimana caranya supaya saat campur dengan suami tetap nyaman selama menopause ini, ada gak obat-obatan yang membantu mengurangi gejala yang gak nyaman"(Pl).

Semua partisipan mengungkapkan tidak pernah mendapatkan pelayanan kesehatan seksual dari petugas kesehatan. Contoh ungkapan partisipan sebagai berikut:

"saya belum pernah menerima pelayanan apa-apa tentang menopause ini hanya sekilas tentang menopause aja dari dokter umum..."(P1).

\section{Pembahasan}

Makna Hubungan Seksual. Makna hubungan seksual dipersepsikan sebagai suatu bentuk cinta dan kasih sayang, kebutuhan yang harus dipenuhi, kewajiban seorang istri, dan keintiman yang lebih dengan pasangan. Ini sejalan dengan penelitian Clarke (2006) yang melaporkan bahwa hubungan seksual pada saat menopause merupakan aspek penting dalam kepuasan hubungan perkawinan. Hubungan seksual tetap diperlukan, sebagai lambang kecintaan dan kemesraan bagi setiap pasangan baik muda maupun tua (Pakasi, 2000).

Makna hubungan seksual selain lambing kecintaan juga menjadi makna lainnya. Makna hubungan seksual yang lainnya adalah sebagai kebutuhan yang harus dipenuhi. Hal ini sangat sejalan dengan Kozier, Erb, Berman dan Snyder (2003) yang menyatakan bahwa seksualitas merupakan salah satu aspek dari kebutuhan dasar manusia dalam kelangsungan kehidupannya.

Perubahan Siklus Respon Seksual pada Masa Menopause. Hasil penelitian ini menunjukkan bahwa semua partisipan mengalami perubahan pada respon seksual. Fase rangsangan (excitement dan plateau) menjadi lebih memanjang. Fase orgasme tidak terjadi sehingga ada ketidakpuasan dalam berhubungan seksual dan fase resolusi yang tidak terjadi perubahan dibanding sebelum menopause.

Dimensi fisiologis ini mencakup siklus respon seksual yang terdiri dari fase excitement, plateau, orgasm dan resolution (Masters \& Johnson, 1966 dalam Freedman, 2009). Pada masa menopause terjadi penurunan sirkulasi estrogen yang mengakibatkan mayoritas perempuan menopause mengalami perubahan dalam fungsi 
seksualnya yaitu kesulitan mencapai orgasme (Dennerstein, Koochaki, Barton, \& Graziottin, 2006; McCoy, 2002).

Ketidaknyamanan lainnya adalah perubahan fungsi seksual seperti penurunan gairah atau hasrat seksual, nyeri saat berhubungan seksual karena lubrikasi pada vagina yang berkurang, dan penurunan durasi hubungan seksual. Keluhan ini mengakibatkan adanya ketidakpuasan dalam berhubungan seksual, dan berkurangnya frekuensi melakukan hubungan seksual. Hal ini sejalan dengan beberapa penelitian sebelumnya yaitu perempuan menopause yang tidak menggunakan hormone replacement therapy (HRT) mengalami perubahan dalam berhubungan seksual yaitu penurunan hasrat seksual, penurunan frekuensi hubungan seksual, penurunan kepuasan hubungan seksual, dan ketidaknyamanan pada vagina seperti vagina yang kering, serta dispareunia (Bachman, et al., 1985; Dennerstein \& Lehert, 2004; Holte, 1992; Huerta, Mena, Malacara, \& de León, 1995).

Faktor yang menyebabkan dispareunia yaitu menipisnya mukosa vagina, berkurangnya elastisitas pada tonus otot genitalia dan pelvis, dan hilangnya lemak pada labia mayora dan labia minora (Riley, 1991; \& Hunter, 1996). Penelitian Tina dan Dwia (1999) menyebutkan bahwa keluhan ketidaknyamanan yang sering terjadi pada perempuan meliputi berkurangnya cairan vagina yang dianggap sebagai hal yang paling mengganggu karena dapat menyebabkan iritasi dan nyeri pada vagina saat berhubungan intim.

Hal ini juga tentukan pada penelitian ini berkaitan dengan frekuensi peneliti untuk melap[orkan tentang b erkurangnya frekuensi hubungan Tina dan Dwia (1999) juga melaporkan bahwa hampir semua responden dalam penelitiannya mengakui lebih jarang melakukan hubungan intim dibandingkan dengan dua sampai tiga tahun sebelum menopause. Penelitian serupa juga telah dilakukan Yangin, et al. (2008) yang melaporkan bahwa sejumlah 66,3\% perempuan melakukan hubungan seksual sebanyak 2-3 kali dalam seminggu sebelum menopause, tetapi saat menopause menjadi seminggu sekali.

Upaya meningkatkan kenyamanan fisik dalam berhubungan seksual yaitu permintaan verbal kepada suami untuk melakukan hubungan seksual secara perlahan. Berkurangnya lubrikasi vagina dianggap wajar bagi perempuan menopause sehingga mereka tidak menggunakan apapun, walaupun ada juga yang menggunakan jelly atau pelumas. Tina dan Dwia (1999) menyampaikan bahwa para perempuan menopause di Bugis Makasar mendiamkannya saja, atau mengkonsumsi buahbuahan yang berair lebih banyak, makan telur mentah dicampur dengan minyak, mengoleskan minyak seperti baby oil atau minyak Madura pada penis suaminya, serta mengoleskan salep mata kadar ringan pada vagina.

Suami dalam penelitian ini tidak mempermasalahkan perubahan yang tampak pada istrinya saat berhubungan seksual. Hal ini sejalan dengan penelitian Tina dan Dwia (1999) yang mengungkapkan bahwa selama istri masih melayani kebutuhan seksual suami dengan baik dan tidak ada hal yang menggangu, meskipun istrinya mengalami masalah atau ketidaknyaman ketika berhubungan. Para suami merasa bahwa kondisi tersebut sama sekali tidak menurunkan hasrat seksualnya untuk berhubungan intim.

\section{Dimensi Psikologis dalam Seksualitas.}

Dillaway (2005) melaporkan bahwa menopause merupakan bagian dari sebuah proses penuaan. Para perempuan memandang bahwa menopause membawa dirinya menjadi tua yang menyebabkan kecantikannya pudar sehingga merasa dirinya tidak sempurna (Kaulagekar, 2010). Hal ini sejalan dengan hasil penelitian ini yang menunjukkan ada partisipan yang memandang dirinya tidak sempurna lagi karena merasa dirinya sudah mulai tua, kulit keriput, rambut sudah banyak beruban, dan tidak lagi cantik. Partisipan bagaimanapun merasa masih sangat berarti bagi suami dan keluarganya. Hal ini sesuai dengan penelitian Kaulagekar (2010) yang menyatakan bahwa arti kesempurnaan 
diri saat menopause dengan hilangnya kesuburan bagi perempuan menopause adalah mereka menjadi merasa sangat menghargai kehidupan berkeluarga khususnya dengan suami dan anak.

Dimensi psikologis lainnya yang teridentifikasi dalam penelitian ini yaitu harga diri. Partisipan tetap percaya diri meskipun sudah menopause dan mengalami ketidaknyamanan saat berhubungan seksual, tetapi karena pasangan yang tidak mempermasalahkan segala perubahan pada dirinya maka perempuan tetap merasa percaya diri dalam menjalankan kewajiban menjalankan fungsi seksualnya. Hal ini sejalan dengan penelitian yang dilakukan oleh Tina dan Dwia (1999) yang menyatakan meskipun perempuan mengeluh ada ketidaknyamanan dalam berhubungan seksual, hal itu tidak membuat perempuan merasa rendah diri apalagi takut kehilangan suami.

Beberapa partisipan peneliltian merasa kurang percaya diri. Ini karena kekhawatiran terhadap segala perubahan yang dialaminya akan mengakibatkan ketidakpuasan suami. Hal ini sejalan dengan penelitian Giblin (2005) yang menemukan bahwa gambaran diri yang negatif tentang aspek seksualitas saat menopause berkaitan dengan perubahan yang terjadi seperti memudarnya kecantikan dan fungsi seksualnya sehingga menyebabkan perasaan rendah diri dan selalu berpikiran negatif.

Semua partisipan mengungkapkan bahwa peran seksual dalam kehidupan rumah tangganya selalu dilakukan oleh suami dengan berinisiatif untuk memulai melakukan hubungan seksual. Hal ini sejalan dengan penelitian Tina dan Dwia (1999) yang menyatakan bahwa semua responden berpegang teguh untuk tidak berinisiatif memulai hubungan seksual. Mereka hanya menunggu suami yang memulai.

Dimensi psikologis lainnya yaitu masalah kesehatan emosional. Dimensi psikologis pada seksualitas meliputi masalah atau gangguan psikiatrik yang dapat mempengaruhi kemampuan seksual seperti kecemasan, depresi, penggunaan obat psikotropika, kepuasan dalam membina hubungan, dan riwayat penyalahgunaan seksual (Youngkin \& Davis, 2003; dan Otong, 2003).

Dimensi Sosiokultural dalam Seksualitas. Suami menilai istrinya sebagai perempuan yang istimewa dan sempurna karena telah menjadi ibu yang baik sampai saat menopause. Kehidupan seksual yang sehat ditandai dengan hubungan seksual yang lancar dan tidak bermasalah. Kehidupan seksual seharusnya dilandasi oleh hubungan antar pribadi yang harmonis dalam kehidupan sehari-hari. Sikap menghargai serta kesediaan untuk mengekspresikan perhatian dan rasa sayang satu sama lain akan berdampak positif pada hubungan seksualnya (Windu, 2009).

Perempuan menopause dalam mitos atau anggapan budaya pada studi disebut sudah "baki atau gabuk", perempuan yang sudah tidak sempurna lagi, dan perempuan yang sudah tidak bisa memberikan kepuasan terhadap suaminya. Perbedaan budaya mempengaruhi penilaian seseorang terhadap dirinya. Budaya barat memandang bahwa menopause merupakan suatu tanda berakhirnya fertilitas perempuan (Chornesky, 2010). Budaya perempuan di Indonesia menurut penelitian Tina dan Dwia (1999) memandang bahwa saat menopause sekitar $62,2 \%$ perempuan merasa bersih atau bermakna suci. Kondisi ini dinilai demikian karena perempuan menopause memiliki kelebihan dibandingkan dengan perempuan yang belum menopause. Menopause dirasakan sangat menyenangkan dan meringankan tugas mereka karena menstruasi dianggap sebagai penyakit bulanan yang sangat merepotkan.

Peran istri dalam dimensi seksualitas menurut pandangan budaya. Dalam studi ini kebanyakan partisipan yang mayoritas bersuku Jawa menganggap bahwa pamali atau pantang bagi istri berinisiatif lebih dahulu atau memulai hubungan seksual. Seksualitas dalam nilai budaya Jawa inilah yang membuat perempuan Jawa sangat menjaganya dengan tidak mengambil peran aktif dalam ekspresi hasrat seksualnya (Ford, Shaluhiyah, \& Suryoputro, 2007). 
Pandangan partisipan dalam penelitian ini sejalan dengan penelitian Tina dan Dwia (1999) yang menemukan bahwa sebanyak 87,2\% perempuan menopause di daerah BugisMakassar mempersepsikan bahwa istri sebagai pihak yang harus paham membawa martabat diri di depan suami. Secara sosiologis diakui bahwa perilaku seksual ini tidak dibentuk secara individual, tetapi merupakan bagian dari proses imitasi, identifikasi, ataupun sosialisasi nilai di masyarakat (Potter \& Perry, 2004).

Kebahagiaan Seksualitas pada Masa Menopause. Kebahagiaan seksualitas pada penelitian ini meliputi terbebas dari penggunaan alat kontrasepsi dan tidak khawatir terjadinya kehamilan. Hal ini sangat sejalan dengan penelitian Tina dan Dwia (1999) bahwa setelah datang masa menopause dirinya berkeyakinan tidak perlu lagi menggunakannya, dan sekarang tidak perlu khawatir lagi akan terjadinya kehamilan karena sudah menopause.

Kebutuhan Informasi tentang Pelayanan Kesehatan Seksual. Hasil penelitian ini didapatkan bahwa semua partisipan mengungkapkan bahwa kebutuhan kesehatan seksual yang saat ini diperlukan meliputi cara untuk mengurangi keluhan ketidaknyamanan saat melakukan hubungan seksual. Hasil penelitian Gott dan Hinchiff (2003) melaporkan bahwa hambatan yang mempengaruhi seseorang khususnya orang tua dalam mencari informasi berkaitan dengan masalah kesehatan seksual meliputi karakteristik demografi, sikap dan nilai yang dimiliki tentang masalah seksual, perasaan malu, takut, anggapan bahwa masalah kesehatan seksual bukan masalah serius, kurangnya pengetahuan mengenai harus kemana saat mengalami masalah tersebut. Inilah yang menyebabkan mereka mencari pelayanan kesehatan seksual.

\section{Kesimpulan}

Penelitian ini menghasilkan enam tema yang diperoleh terkait dengan pengalaman seksualitas perempuan menopause sebagai berikut: makna hubungan seksual, perubahan siklus respon seksual pada masa menopause, dimensi psiko- logis dalam seksualitas, dimensi sosiokul-tural dalam seksualitas, kebahagiaan seksualitas pada masa menopause, dan kebutuhan informasi tentang pelayanan kesehatan seksual.

Saran pada penelitian ini perawat dan tenaga kesehatan lainnya mendapatkan gambaran tentang kebutuhan seksualitas khususnya pada masa menopause yang sebenarnya hal ini masih dianggap tabu oleh masyarakat maupun di kalangan tenaga kesehatan sendiri. Perawat akan dapat meningkatkan pemahamannya, khususnya mengenai aspek seksualitas yang tidak hanya terbatas pada dimensi fisiologis saja melainkan dimensi lainnya yaitu psikologis dan sosiokultural.

Perawat dapat berupaya meningkatkan pelayanan kesehatan reproduksi pada perempuan khususnya kesehatan seksualitas khususnya pengembangan program promosi kesehatan mengenai kesehatan seksualitas di kalangan perempuan menopause maupun landasan dalam memberikan asuhan keperawatan pada perempuan menopause (AT, YR, HR).

\section{Referensi}

Bachmann, G.A., Leiblum S.R., Sandler B., Ainsley W., Narcessian R., Shelden R., \& Hymans, H.N. (1985). Correlates of sexual desire in post menopausal women. Maturitas, 7(3), 211-216.

Badan Pusat Statistik. (2005). Angka harapan hidup. Diperoleh dari http://demografi. bps.go.id/versi1/index.php?option=com_tabel $\&$ kat $=5 \&$ idtabel $=132 \&$ Itemid $=167$.

Barsky, J.L., Friedman, M.A., \& Rosen, R.C. (2006). Sexual dysfunction and chronic illness: The role of flexibility in coping. $J$ Sex Marital Ther; 32 (3), 235-253.

Chornesky, A. (2010). Multicultural perspective on menopause \& the climacteric. Affilia Spring, $13,31-46$.

Clarke, H.L. (2006). Older women and sexuality: Experiences in marital relationships across 
the life course. Canadian J. on Aging, 25(2), 129-140.

Dennerstein, L., \& Lehert, P. (2004). Wo-men's sexual functioning, lifestyle, mid-age, and menopause in 12 European countries. Menopause, 12 (6), 778-785.

Dennerstein L, Koochaki P, Barton I, Graziottin, A. (2006). Hypoactive sexual desire disorder in menopausal women: A survey western European women. The $J$ of Sexual Medicine, 3 (2), 212-222.

Dillaway, H. (2005). Changing menopausal bodies: How women think and act in the face of a reproductive transition and gendered beauty ideals. Sex Roles: A Journal of Research, 53 (1-2). 1-17.

Ford, J.N., Shaluhiyah, Z., \& Suryoputro, A. (2007). A rather benign sexual culture: Sociosexual lifestyle of youth in urban central Java, Indonesia. Population, Space, and Place, 13 (1), 59-76.

Freedman, M.A. (2009). Partnership issues and sexuality. Clin Obstet Gynecol. 52(4), 656665. DOI: 10.1097/GRF. 0b013e3181bf4804.

Giblin, L., K. (2005). Sex and menopause: The sizzle and the fizzle. Sexuality, Reproduction \& Menopause, 3 (2), 72-77.

Goberna, J., Frances, L., Pauli, A., Barluenga, A., \& Gascon, E. (2009). Sexual experiences during climacteric years: What do women thing about it? Maturitas, 62 (1), 47-52.

Goncalves, R., \& Merighi, MAB. (2009). Reflection on sexuality during the climacteric. Latino-am Enfermagem, 17 (2), 160-166.

Gott, M., \& Hinchliff, S. (2003). Barriers to seeking treatment for sexual problems in primary care: A qualitative study with older people. Family Practice, 20 (6), 690-695.

Hartmann, U., Phillippsohn, S., Heiser, K., \& Ruffer-Hesse, C. (2004). Low desire in mildlife and older women: Personality factors, psychosocial development, present sexuality. Menopause, 11 (6 Pt 2), 726-740.
Holte, A. (1992). Influence of natural menopause on health complaints: A prospective study of healthy Norwegian women. Maturitas, 14 (2), 127-141.

Huerta, R., Mena, A., Malacara, J.M., \& de León, J.D. (1995). Symptoms at perimenopausal period: Its association with attitude toward sexuality, life style, family function, and FSH level. Psycho-neuroendocrinology, 20 (8), 135-167.

Hunter, M. (1996). Depression and the menopause. British Medical Journal, 313 (7067), 1217-1218.

Jinzhu, L., \& Eden, J. (2007). Experience and attitudes toward menopause in Chinese women living in Sydney: A cross sectional survey. Maturitas, 58 (4), 359-365.

Kaulagekar, A. (2010). Menopause and feminimity: Qualitative enquiry into menopause of urban women from Pune, Maharashtra. Anthropologist, 12 (1), 23-26.

Kozier, B., Erb, G., Berman, A., \& Snyder, S. (2003). Fundamentals of nursing: Concepts, process, and practice (7th Ed.). New Jersey: Prentice-Hall.

Mayo, J.L. (2000). A natural approach to menopause. Advanced Nutrition Publication, $5(7), 5-13$.

McCoy, L.N. (2002). Longitudinal study of menopause and sexuality. Acta Obstet Gynecol Scand, 81 (7), 617-622.

Otong, A.D. (2003). Psychiatric nursing: Biological and behavioral concept. New York: Delmar Cengage Learning.

Pakasi, S.L. (2000). Menopause: Masalah dan penanggulangannya. Jakarta: Penerbit FKUI.

Potter, A.P. \& Perry, G.A. (2004). Fundamentals of nursing (6th Ed.). St Louis: Mosby.

Riley, A.J. (1991). Sexuality and the menopause. Sexual \& Marital Therapy, 6 (2), 135-46. 
Schultz-Zehden, B., \& Rosemeier, H.P. (1998). Medizin psychologische aspect desklimakterium. Psychomed, 7, 217-222.

Tina, N.K., \& Dwia, A. (1999). Menopause dan seksualitas (Seri Laporan no. 87). Yogyakarta: Pusat Penelitian Kependudukan Universitas Gadjah Mada.

Windu, C.S. (2009). Disfungsi seksual. Yogyakarta: Andi Yogyakarta.
Yangin, B.H., Sözer, A.G., Sengün, N., \& Kukulu, K. (2008). The relationship between depression and sexual function in menopause period. Maturitas, 61 (3), 233237.

Youngkin, E.Q. \& Davis, M. (2003). Women's health: A primary care clinical guide (3rd Ed.). New Jersey: Prentice Hall. 